\title{
The Destruction of the Medieval Chinese Aristocracy
}

Review Number: 1807

Publish date: Thursday, 30 July, 2015

Author: Nicolas Tackett

ISBN: 9780674492059

Date of Publication: 2014

Price: $£ 36.95$

Pages: 298pp.

Publisher: Harvard University Press

Publisher url: http://www.hup.harvard.edu/catalog.php?isbn=9780674492059

Place of Publication: Massachusetts

Reviewer: Michael Hoeckelmann

In 845, Li Deyu ??? (787-850), arguably the most powerful man of the realm at that time and scion of one of the great aristocratic clans of medieval China, submitted a 'Stele Inscription for Commemorating the Sagely Deeds in Youzhou, with preface' ('Youzhou ji shenggong beiming bing xu' ?????????) to Emperor Li Yan ?? (r. 840-46), better known under his temple name Wuzong ??. The inscription was either never carried out or later destroyed, because we only have its transmitted version in Li's anthology and the biography of its addressee, Zhang Zhongwu ??? (d. 849), military commissioner of Youzhou, in Old History of the Tang ( Jiu Tangshu ???).(1) The rhymed inscription praises Zhang in grandiloquent terms, without saying much about the substance of his deeds. The interesting part, as with most Tang inscriptions, is the preface. There we learn how Zhang had been crucial in wiping out a large group of Uighurs that had fled to Youzhou after the collapse of their empire in 840, and the rebellion of the military commissioner of Zhaoyi ??, Liu Zhen ?? (d. 844). The Tang court had been able to install Zhang as military commissioner in 841, against two other contenders from the Lulong ?? army in Youzhou. Li Deyu had convinced the court that Zhang, who reportedly was over 50 at that time and trusted by soldiers in his own Chengde ?? circuit and the Lulong army, in which his father had served, was the candidate most loyal to the dynastic cause. Even though, Zhang 'could not be forced to do anything against his will', and it seems that he postponed final action against the Uighurs until 845.

Every student of Chinese history knows that most parts of China after the Rebellion of An Lushan ??? (755-63) had slipped from the grasp of the court; that military commissioners (jiedushi ???) ruled in its stead by wielding charismatic leadership over their armies ('semi-autonomous' is the phrase commonly used) and embezzling the tax-money badly needed in Chang' an ??. The century-and-a-half until the end of the dynasty - by then nothing but an empty hull - were one unending, pathetic fiasco, and when it finally came in 907, it came as a release. Tackett sets out to shatter that narrative, and he does so spectacularly. Tackett's book follows two objectives: one is to rewrite the demise of the medieval Chinese aristocracy; the other is to show that the court by 820 , contrary to received knowledge, had regained control over most parts of the realm, with the notable exception of the three Hebei ?? provinces - Chengde, Weibo ??, and Youzhou. He makes use of an enormous trove of epigraphic remains that has come to light during the last decades due too China's rapid modernisation and the accompanying digging, constructing, tunnelling, etc.: thousands of 'interred tomb epitaphs' (muzhiming ???) of the Tang elite from all-over China, but in particular from the 
If one is allergic to numbers and shares Churchill's sentiment that 'I only believe in statistics that I doctored myself', then a book that offers quite a few of both can be a little off-putting. However, Tackett manages to weave the numbers into a thrilling and convincing account of what happened to the great clans of medieval China at the turn from the ninth to the tenth century. His thesis is that the medieval Chinese aristocracy did not peter out into insignificance throughout the Tang, caused by increased reliance of the state on civil service examinations since the reign of Wu Zetian ??? (690-705) and aggravated by An Lushan, but was wiped out in the wake of the Rebellion of Huang Chao ?? in the 870s and 880s, his sack of Chang' an and Luoyang, and the violence that ravaged the corridor between the two capitals and the pockets of émigré clans of the Southern Dynasties (316-589) in the Lower Yangzi region. The onslaught was much eased by the clustering of the elite in few metropolitan areas, and if there is one point every Tang historian should take from this book, then it is that even though members of the great clans were proud of their 'choronyms', i.e. two-character place names added before the usually one-character family names, few if not almost none of them still had a physical base in the places those choronyms indicated (e.g., Li Deyu, member of the Zanhuang ?? county branch of the Zhaojun ?? [jun = prefecture] Lis, probably never sat foot into Zhaojun, let alone Zanhuang). Literature also shows that this was a metropolitan culture, its authors yearning for the capitals even when in the remotest corner of the empire. Tackett rightly calls the relationship between centre and periphery 'colonial' (p. 25).

Hence, Huang Chao was much more decisive in bringing about the sweeping social changes captured in the 'Tang-Song Transition' model than its overrated precursor An Lushan. This in itself is a provocative thesis, and Tackett backs it up with ample of evidence. Here he sometimes slips into enumerating case after case, not unusual for a historian working quantitatively. For an intellectual historian, the central statement of the book is somewhat undeservedly relegated into a footnote on page 230 :
'It is worth considering why the idea of the greater severity of the An Lushan Rebellion persists in scholarly literature. [...] One explanation for the persistent exaggeration of the rebellion's impact is simply the influence on scholars of the pervasive references to An Lushan in eighth- and ninth-century literature. By contrast, far fewer poets and prose writers of distinction survived into the tenth century to tell tales of post-Huang Chao devastation.' (p. 230, Fn. 140)

The abysmal condition of the sources for the last 50-odd years of the Tang due to the destruction of records in Chang' an by the rebels under and following Huang Chao is a well-known fact to historians. Sima Guang ??? (1019-1086) time and again gives differing accounts of that period in the 'scrutinising variants' (kaoyi ??) section of his Comprehensive Mirror to Aid in Government (Zizhi tongjian ????), quoting from sources that have not survived or only in fragments, that it seems impossible to know the real course of events. To aggravate things, most standard accounts of that period, the great narratives of eunuch dominance and factionalism at court, were, if not invented, then at least shaped by Song ? (960-1279) perceptions and biases; and the literature containing 'pervasive references to An Lushan in [the] eighth and ninth century' was likewise to a large degree compiled under the Song.

Tackett begins with a recount of the standard model of 'aristocratic' medieval China: In contrast to the second millennium, when success in the civil service examinations was a prerequisite for any official career, medieval China from the Eastern Han ?? (25-220 AD) through to the ninth century was dominated by a stable number of clans which, for lack of another term, are often called 'aristocracy' or 'oligarchy' (shizu ??) by scholars in East and West. It is easier to show how these clans did not maintain their positions for such a long time than how they actually did, because they were not landowners that based their claim to political participation on wealth or military feats; instead, they maintained their status by producing many officeholders over time. One of their ancestors may have been classified into one of 'nine ranks' (jiupin ??) by the beginning of the third century. That rank determined on which level an individual entered officialdom and how far he could climb, and originally applied to individuals, but became hereditary over time. One cannot 
emphasise enough, though, that it was not offices that were hereditary - the only hereditary office, at least in theory, being that of Emperor. Instead, education and culture (or 'breeding') were thought of being hereditary, and Tackett points to the possible influence of Buddhism on this 'karmic' concept of accumulated virtue (p. 29).

The ranks were discontinued in the late sixth century, but their continued prestige had a pervasive influence on elite society that credited pedigree more than anything else for a person success in life throughout the Tang. As Tackett shows and, indeed, many have shown before him, only descendants of those clans that could trace their ancestry to before the Tang rose to the highest positions in government. One means by which these clans monopolised the bureaucracy was a privilege called 'protection' (yin ?), which allowed an official to give one or several of his descendants a kick-start in life. Only from the Song onwards did the civil service examination gradually become the defining feature of the Chinese state and, in fact, create a completely new type of elite (often called 'gentry', but that is another story). The crucial question that has plagued generations of scholars is: How did the great clans decline and eventually disappear? Because from the late tenth century on, we have almost no high ministers from these clans in the biographical sections of the standard (often called 'dynastic') histories, while they completely dominated the scene between the third and ninth.

After reviewing earlier scholarship based on clan lists - transmitted, palaeographic, or reconstructed by modern scholars - and samples of epitaphs (4), Tackett moves on to the distribution of those great clans or, as he prefers to call them, 'capital elite', based on the newly discovered epitaphs. He locates individuals and their relations - by birth or marriage - based on the place burial (i.e., the place the epitaph was discovered); to enable his quantitative analysis, Tackett compiled a database of all excavated epitaphs that have hitherto been published in mainland China, containing personal information on the addressee, his or her relations, which offices held and where, the author of the inscription, etc. The database can be downloaded from the authors and the publisher's webpages for free, which is a highly useful tool for future research, and for this alone Tackett deserves the applause and immense gratitude of every Tang historian. Tackett shows that the great clans as a 'national elite' managed to retain their grip on all high positions in the capitals and provinces after the An Lushan Rebellion until the eve of the Huang Chao Rebellion and that they, despite their choronyms and with only few exceptions, had their homesteads in Chang'an, Luoyang, or the capital corridor (when they were not on tenure in the provinces, which usually did not last longer than three years). He even rescues Chen Yinque's (or -ke's) ??? (1890-1968) model of the composition of the Tang elite from the grave, which has fallen into disrepute since its formulation in the 1940s. Chen famously argued for a bifurcation of the 'factions' in ninth-century politics along the lines of pedigree and economic background: an 'East Coast Aristocracy' from Shandong ?? and Hebei (the marriage-ban clans, Tackett's clique A), dating back to before the Tang, and a circle of upstart families from around Chang' an that included the imperial clan (clique B), which came to power only after Wu Zetian enhanced the import of the civil service examinations (pp. 122-9).

The analysis of the geographic distribution of the national elite clans in chapter two and their marriage networks in chapter three is complemented by a depiction of the political composition of the three independent Hebei provinces, on which Tackett has another monograph in preparation, in chapter four, and of the literary representations of the Huang Chao Rebellion in chapter five.

One weakness of Tackett's argument is that he often jumps to conclusions from rather meagre evidence. Any scholar who has dealt with muzhiming knows of their richness in flowery language, but paucity in content, and the author may have raised this issue in the introduction. The mere affirmation that epitaphs 'express the values and ideals of the society of the time' (p. 13) seems more like a fig leaf. It also leads Tackett into more than one argument ex silentio, betrayed by repeated assertions that, even though the inscriptions do not divulge plenty of evidence, his claims stood beyond reasonable doubt, and by formulations such as this: 'Although some accounts of ancestral flight [i.e. the migration of a clan in the past] might have been fabricated, most were almost certainly accurate' (p. 55) - after which the reader is left to wonder what degree of accuracy is captured by 'almost certainly'. Another weakness is his continued cross-referencing to 
other chapters, which, though sometimes useful, becomes tedious after a while. Finally, although Tackett's database contains 'basic prosopographic data on over 30,000 individuals' (Appendix A, p. 243) correlated with ca. 17,500 members of the capital elite from the tables of ministers in New History of the Tang (Xin Tangshu ???), excavated epitaphs account for only 2.59 per cent of the latter total (p. 248-9) - a disturbingly slim basis. On the other hand, his statistical approach seems sound, when at the end of page 249 he calculates the male members of the capital elite at any given point during the ninth century as roughly 19,700 , thus equalling the number given by Twitchett for officials 'in the current' $(19,000)$ at the onset of the eighth century 40 years ago. $\underline{(5)}$

However, above points should not be misunderstood, they are mere beauty spots on a work that will revolutionise our understanding of medieval China. Tackett's work on the composition of the political and social elite in ninth-century China is a milestone, and it should encourage scholars to pick up where he left his account of the destruction of the medieval Chinese aristocracy.

\section{Notes}

1. Liu Xu ?? (888-947) et al., Old History of the Tang (16 vols, Beijing, 1975), 180.4678-9.Back to (1)

2. Quoting Michael R. Drompp, Tang China and the Collapse of the Uighur Empire: A Documentary History (Leiden, 2005), p. 143, see ibid. pp. 76-8, 142-45, et passim.Back to (2)

3. See inter alia Rainer von Franz, Die chinesische Innengrabinschrift für Beamte und Privatiers des 7. Jahrhunderts (Stuttgart, 1996).Back to (3)

4. Most representative among Western scholarship are David Johnson, The Medieval Chinese Oligarchy (Boulder, CO, 1977) and Patricia Buckley Ebrey, The Aristocratic Families of Early Imperial China: A Case Study of the Po-ling Ts'ui Family (Cambridge, 1978).Back to (4)

5. D. Twitchett, The Birth of the Chinese Meritocracy: Bureaucrats and Examinations in T'ang China (London, 1976), p. 7. Back to (5)

Source URL:https://reviews.history.ac.uk/review/1807

\section{Links}

[1] https://reviews.history.ac.uk/item/112723 